\title{
Phase Relations Between Palladium Oxide and the Rare Earth Sesquioxides in Air
}

\author{
C. L. McDaniel and S. J. Schneider \\ Institute for Materials Research, National Bureau of Standards, Washington, D.C. 20234
}

(August 22, 1967)

\begin{abstract}
The equilibrium phase relations were determined in an air environment between $\mathrm{PdO}$ and each of the following: $\mathrm{La}_{2} \mathrm{O}_{3}, \mathrm{Nd}_{2} \mathrm{O}_{3}, \mathrm{Sm}_{2} \mathrm{O}_{3}, \mathrm{Eu}_{2} \mathrm{O}_{3}, \mathrm{Gd}_{2} \mathrm{O}_{3}, \mathrm{Dy}_{2} \mathrm{O}_{33}, \mathrm{Ho}_{2} \mathrm{O}_{3}, \mathrm{Y}_{2} \mathrm{O}_{33}, \mathrm{Er}_{2} \mathrm{O}_{33}, \mathrm{Tm}_{2} \mathrm{O}_{3}, \mathrm{Yb}_{2} \mathrm{O}_{3}$, and $\mathrm{Lu}_{2} \mathrm{O}_{3}$. In air $\mathrm{PdO}$ dissociates to $\mathrm{Pd}$ metal at $800{ }^{\circ} \mathrm{C}$. The dissociation of $\mathrm{PdO}$ is apparently a reversible process. The $\mathrm{Nd}_{2} \mathrm{O}_{3}-\mathrm{PdO}$ and $\mathrm{Sm}_{2} \mathrm{O}_{3}-\mathrm{PdO}$ systems were studied in detail inasmuch as they typified several of the $\mathrm{Ln}_{2} \mathrm{O}_{3}-\mathrm{PdO}$ systems. Three compounds, $2 \mathrm{Nd}_{2} \mathrm{O}_{3} \cdot \mathrm{PdO}$, metastable $\mathrm{Nd}_{2} \mathrm{O}_{3} \cdot \mathrm{PdO}, \mathrm{Nd}_{2} \mathrm{O}_{3}$ $2 \mathrm{PdO}$ occur in the $\mathrm{Nd}_{2} \mathrm{O}_{3}-\mathrm{PdO}$ system. The 2:1, 1:1, and 1:2 compounds, of unknown symmetry, dissociate or decompose at 1135,860 , and $1085^{\circ} \mathrm{C}$, respectively. The $2: 1$ compound dissociates to the solid phases, $\mathrm{Nd}_{2} \mathrm{O}_{3}$ and $\mathrm{Pd}$. No further reactions occur between $\mathrm{Nd}_{2} \mathrm{O}_{3}$ and $\mathrm{Pd}$ up to $1300{ }^{\circ} \mathrm{C}$. Three compounds, 2:1, metastable $1: 1$, and $1: 2$ occur in the $\mathrm{Sm}_{2} \mathrm{O}_{3}-\mathrm{PdO}$ and $\mathrm{Eu}_{2} \mathrm{O}_{3}-\mathrm{PdO}$ systems. Two compounds, 2:1 and 1:2 occur in the $\mathrm{La}_{2} \mathrm{O}_{3}-\mathrm{PdO}$ system. Other compounds detected were the 1:1 and $1: 2$ in the $\mathrm{Gd}_{2} \mathrm{O}_{3}-\mathrm{PdO}$ system and the metastable 1:1 in the $\mathrm{Dy}_{2} \mathrm{O}_{3}-\mathrm{PdO}$ system. Each of these compounds subsequently dissociated upon heating. No apparent reaction occurred between PdO and either $\mathrm{Ho}_{2} \mathrm{O}_{3}, \mathrm{Y}_{2} \mathrm{O}_{3}, \mathrm{Er}_{2} \mathrm{O}_{3}, \mathrm{Tm}_{2} \mathrm{O}_{3}, \mathrm{Yb}_{2} \mathrm{O}_{3}$, or $\mathrm{Lu}_{2} \mathrm{O}_{3}$.
\end{abstract}

Key Words: Dissociation, equilibrium, $\mathrm{Ln}_{2} \mathrm{O}_{3}: \mathrm{PdO}$ compounds, $\mathrm{Ln}_{2} \mathrm{O}_{3}-\mathrm{PdO}$ systems, phase relations.

\section{Introduction}

This study is part of a program to determine what effect, if any, various Pt-group metals have upon the metal oxides when heated together in an oxidizing environment. Several of the Pt-group metals have a ctrong tendency to oxidize when heated in air at moderate temperatures. At higher temperatures in air, these oxides volatilize and dissociate to one solid phase, the metal. Previous work $[1,2]^{1}$ has shown that iridium dioxide reacts with other refractory oxides at moderate temperatures. Considering the fact that several of the Pt-group metals are used as secondary standards on the International Practical Temperature Scale

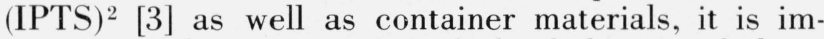
portant to better understand the behavior of these metals in an air environment. This work presents the results of an investigation of the phase relations between palladium oxide $(\mathrm{PdO})$ and the rare earth sesquioxides $\left(\mathrm{Ln}_{2} \mathrm{O}_{3}\right)$ in air.

The $\mathrm{Nd}_{2} \mathrm{O}_{3}-\mathrm{PdO}$ and $\mathrm{Sm}_{2} \mathrm{O}_{3}-\mathrm{PdO}$ systems were studied in detail and were found to be quite similar in many respects. The present study was broadened somewhat to include $\mathrm{PdO}$ in combination with each of the following sesquioxides: $\mathrm{La}_{2} \mathrm{O}_{3}, \mathrm{Eu}_{2} \mathrm{O}_{3}, \mathrm{Gd}_{2} \mathrm{O}_{3}$,

${ }^{1}$ Figures in brackets indicate the literature references at the end of this paper.

2 This scale (IPTS) applies to all temperatures listed in this paper.
2 .
$\mathrm{Dy}_{2} \mathrm{O}_{3}, \quad \mathrm{Ho}_{2} \mathrm{O}_{3}, \quad \mathrm{Y}_{2} \mathrm{O}_{3}, \quad \mathrm{Er}_{2} \mathrm{O}_{3}, \quad \mathrm{Tm}_{2} \mathrm{O}_{3}, \quad \mathrm{Yb}_{2} \mathrm{O}_{3}$, and $\mathrm{Lu}_{2} \mathrm{O}_{3}$. A limited study seemed adequate for these ten systems due to their similarity with the $\mathrm{Nd}_{2} \mathrm{O}_{3}-\mathrm{PdO}$ system or to their apparent lack of reaction.

Palladium ( $\mathrm{Pd}$ ) oxidizes to $\mathrm{PdO}$ when heated in air at moderate temperatures. Palladium oxide rather than Pd metal was selected as one end member of the system, because the latter oxidizes too slowly in air. By utilizing $\mathrm{PdO}$, an approach to equilibrium could be achieved more readily. The study would still reflect, however, the behavior in air of $\mathrm{Pd}$ metal in combination with other oxides.

Palladium has the structure of face-centered cubic copper with $a=3.8898 \AA$ [4]. The freezing point of $\mathrm{Pd}$ is $1552{ }^{\circ} \mathrm{C}$, a value which is given as a secondary reference point on the International Practical Temperature Scale of 1948. The structure of $\mathrm{PdO}$ has been described on the basis of a tetragonal unit cell with $a=3.0434 \AA$ and $c=5.337 \AA$ [5]. Upon heating, PdO has been reported to dissociate to $\mathrm{Pd}$ and a vapor phase at $870^{\circ} \mathrm{C}$ in $1 \mathrm{~atm}$ oxygen [6].

The stable modification of neodymium sesquioxide $\left(\mathrm{Nd}_{2} \mathrm{O}_{3}\right)$ has the hexagonal A type $(a=3.831 \AA$, $c=5.999 \AA$ ) [7] rare earth oxide structure at the temperatures investigated in this study. Samarium sesquioxide $\left(\mathrm{Sm}_{2} \mathrm{O}_{3}\right)$ has been reported to crystallize in the $\mathrm{C}$ form at low temperatures and to invert di- 
rectly and irreversibly in air to the $\mathrm{B}$ type monoclinic structure at about $950{ }^{\circ} \mathrm{C}$ [8]. The unit cell dimensions of $\mathrm{B}$ type $\mathrm{Sm}_{2} \mathrm{O}_{3}$ were reported by Roth and Schneider [8] as $a=14.16 \AA, b=3.621 \AA, c=8.84 \AA$, and $\beta$ $=100.05^{\circ}$. The melting points of $\mathrm{Nd}_{2} \mathrm{O}_{3}$ and $\mathrm{Sm}_{2} \mathrm{O}_{3}$ have been reported to be over $2000{ }^{\circ} \mathrm{C}$ [9].

\section{Materials}

All starting materials employed in this study had a purity of 99.7 percent or greater. With the exception of $\mathrm{PdO}$ and $\mathrm{Y}_{2} \mathrm{O}_{3}$, the oxides were used in other investigations and their spectrochemical analyses were reported previously $[10,11]$. The $\mathrm{PdO}$ and $\mathrm{Y}_{2} \mathrm{O}_{3}$ samples were found by general qualitative spectrochemical analysis ${ }^{3}$ to have the following impurities:

PdO: $0.01-0.1 \%, \mathrm{Fe}$ and $\mathrm{Si}$;

$$
\begin{aligned}
& \text { 0.001-0.01\% each } \mathrm{Al}, \mathrm{Ba}, \mathrm{Ca}, \mathrm{Cu}, \mathrm{Mg}, \mathrm{Pt} \text {, and } \\
& \mathrm{Sr} \text {; } \\
& <0.001 \% \text { each } \mathrm{Ag}, \mathrm{Mn} \text {, and } \mathrm{Pb}
\end{aligned}
$$

$\mathrm{Y}_{2} \mathrm{O}_{3}: 0.01-0.1 \%$, Ca;

0.001-0.01\% each Al, Ho, Tm, and $\mathrm{Yb}$;

$0.0001-0.001 \%$ each $\mathrm{Cu}, \mathrm{Fe}, \mathrm{Lu}$, and $\mathrm{Mg}$.

\section{Experimental Procedure}

Specimens were prepared from $0.4 \mathrm{~g}$ batches of various combinations of $\mathrm{PdO}$ and the rare earth oxides. Calculated amounts of each oxide, corrected for ignition loss, were weighed to the nearest milligram. Each batch was thoroughly hand mixed, placed in fused silica tubes (sealed at one end) and fired in a muffle furnace for a minimum of $18 \mathrm{hr}$ at $770{ }^{\circ} \mathrm{C}$ and at $780{ }^{\circ} \mathrm{C}$. Succeeding each heat treatment, the materials were thoroughly hand mixed and examined by x-ray diffraction techniques.

Following the preliminary heat treatments, portions of each batch were placed in the open silica tubes and fired in a platinum alloy wire-wound quench furnace at various temperatures for different periods of time. The specimen was air quenched by quickly pulling the tube from the furnace. Equilibrium was assumed to have been achieved when the x-ray pattern showed no change after successive heat treatments or when the data were consistent with the results from a previous set of experiments.

Sealed platinum tubes were employed as specimen containers for the experiments having prolonged heat treatments below the dissociation temperatures. Sealed tubes were utilized in an attempt to maintain composition and to obtain maximum reaction. The use of fused silica tubes instead of platinum was necessary because $\mathrm{Pd}$, frequently found as a decom-

${ }^{3}$ The spectrochemical analyses were performed by the Spectrochemical Analysis Section of the National Bureau of Standards. position product, readily reacts with platinum. On the other hand, the silica tube did not appear to influence or react with the various oxide samples.

Temperatures in the quench furnace were measured with a 100 percent $\mathrm{Pt}$ versus 90 percent $\mathrm{Pt}-10$ percent $\mathrm{Rh}$ thermocouple. All reported temperatures pertaining to quench furnace data are considered accurate to within $\pm 5{ }^{\circ} \mathrm{C}$. The precision of the measurements was $\pm 2{ }^{\circ} \mathrm{C}$.

All specimens were examined by x-ray diffraction at room temperature using a high angle recording Geiger counter diffractometer and Ni-filtered $\mathrm{Cu}$ radiation.

\section{Results and Discussion}

\section{1. $\mathrm{Nd}_{2} \mathrm{O}_{3}-\mathrm{PdO}$ and $\mathrm{Sm}_{2} \mathrm{O}_{3}-\mathrm{PdO}$ Systems in Air}

The equilibrium phase diagram for the $\mathrm{Nd}_{2} \mathrm{O}_{3}-\mathrm{PdO}$ system in air is given in figure 1 . The diagram was constructed from the data listed in table 1. The solid circles indicate the compositions and temperatures of the experiments conducted. It should be emphasized that figure 1 represents a composite of the $\mathrm{Nd}_{2} \mathrm{O}_{3}-\mathrm{Pd}$ and $\mathrm{Nd}_{2} \mathrm{O}_{3}-\mathrm{PdO}$ systems in the $\mathrm{Nd}-\mathrm{Pd}$-Oxygen ternary. At the lower temperatures, the oxygen content of the specimens closely conforms to the compositions represented by the pseudobinary system, $\mathrm{Nd}_{2} \mathrm{O}_{3}-\mathrm{PdO}$. At the higher temperatures, the compositions of the solid phases change by an apparent oxygen loss to those indicated by the $\mathrm{Nd}_{2} \mathrm{O}_{3}-\mathrm{Pd}$ join. Figure $\mathrm{l}$ is a pseudobinary representation of a portion of the ternary system. This method of illustration has been employed by a number of investigators [1, 12].

Palladium oxide was found to dissociate to $\mathrm{Pd}$ metal and presumably oxygen at $800 \pm 5{ }^{\circ} \mathrm{C}$ in air at atmospheric pressure. This value compares favorably with the data $\left(870{ }^{\circ} \mathrm{C}\right.$ in one atmosphere oxygen) given by Bell et al., in their study of the Pd-oxygen system [6]. The dissociation of $\mathrm{PdO}$ is a reversible process. Palladium oxide was first heated above 800 ${ }^{\circ} \mathrm{C}$, until only $\mathrm{Pd}$ was present. The same material was then reheated at $790{ }^{\circ} \mathrm{C}$ and the $\mathrm{x}$-ray data indicated only $\mathrm{PdO}$.

Raub [13] reports that palladium takes up appreciable quantities of oxygen into solid solution when the metal is heated in oxygen at $1200{ }^{\circ} \mathrm{C}$. Raub's concluions were based on weight gain data with no x-ray results given. Chaston [14] concluded the weight gain of Pd observed by Raub was due to the oxidation of base metal impurities. The x-ray diffraction data obtained in the present study show no indication of solid solution of oxygen in $\mathrm{Pd}$, when heated in an air environment.

Three intermediate compounds, $2: 1,1: 1$, and $1: 2$ occur in the $\mathrm{Nd}_{2} \mathrm{O}_{3}-\mathrm{PdO}$ system. The stable 2:1 and 1:2 compounds dissociate to two solid phases and a vapor phase, presumably oxygen at 1135 and $1085{ }^{\circ} \mathrm{C}$, respectively. The 1:1 phase was found to decompose at about $860{ }^{\circ} \mathrm{C}$ to the $2: 1$ and $1: 2$ compounds. In order 


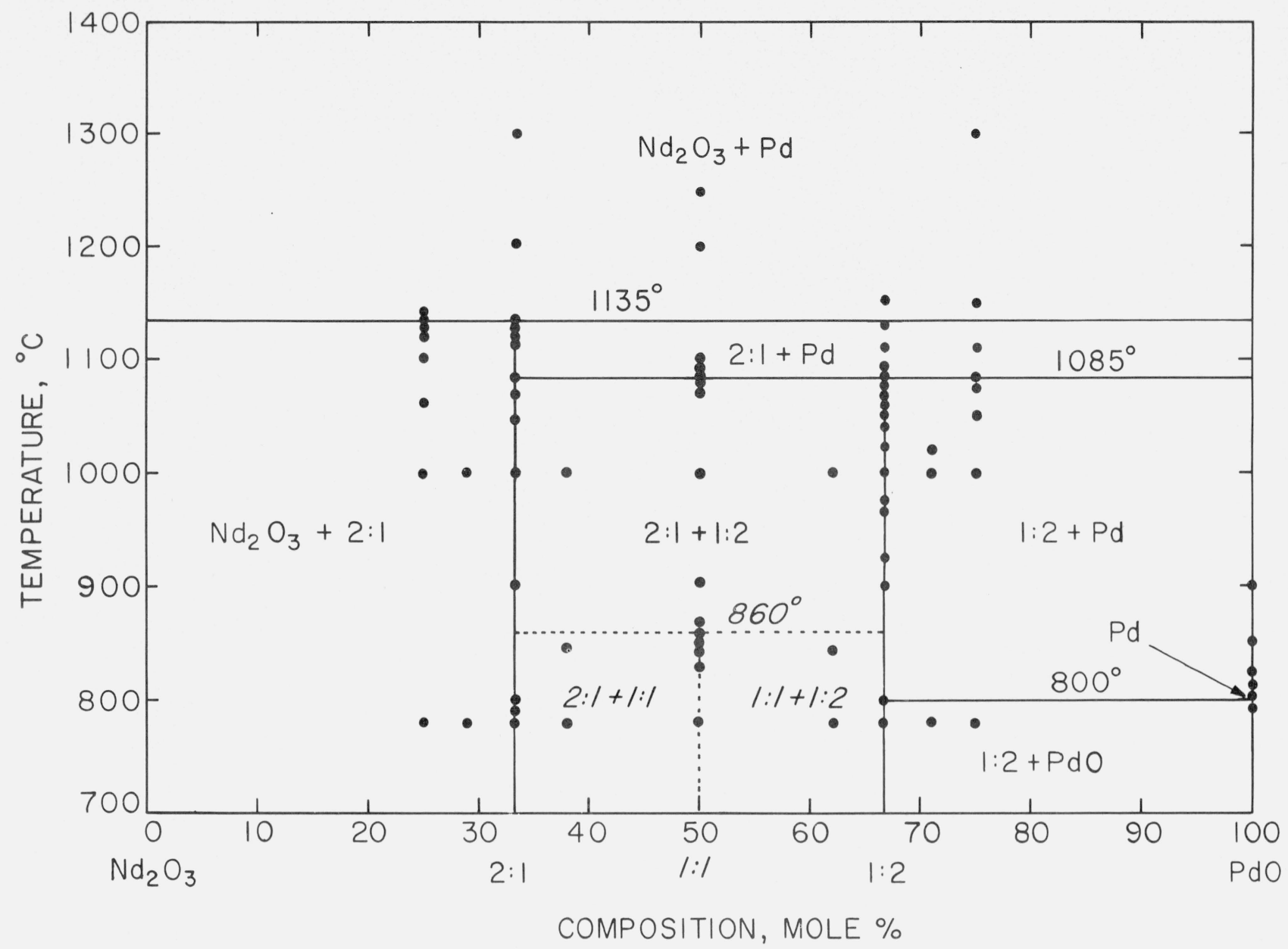

Figure 1. Phase equilibrium diagram for the $\mathrm{Nd}_{2} \mathrm{O}_{3}-\mathrm{PdO}$ system in air.

Dotted lines indicate metastable 1:1 compound and decomposition temperature. Italic lettering indicates metastable phase assemblages.

- compositions and temperatures of experiments conducted.

TABLE 1. Experimental data for compositions in the $\mathrm{Ln}_{2} \mathrm{O}_{3}-\mathrm{PdO}$ systems

\begin{tabular}{|c|c|c|c|c|c|}
\hline \multirow{2}{*}{ System } & \multirow{2}{*}{ Composition } & \multicolumn{2}{|c|}{ Heat treatment ${ }^{a}$} & \multirow{2}{*}{ X-ray diffraction analyses ${ }^{b}$} & \multirow{2}{*}{ Remarks } \\
\hline & & Temp. & Time & & \\
\hline $\mathrm{Nd}_{2} \mathrm{O}_{3}-\mathrm{PdO} \ldots \ldots \ldots \ldots$ & $\begin{array}{c}\text { mole \% } \\
75: 25 \\
\\
71: 29 \\
66.6: 33.3\end{array}$ & $\begin{array}{l}{ }^{\circ} C \\
780 \\
{ }^{\mathrm{c}} 1000 \\
{ }^{\mathrm{c}} 1063 \\
{ }^{\mathrm{c}} 1103 \\
{ }^{\mathrm{d}} 1125 \\
{ }^{\mathrm{c}} 1130 \\
{ }^{\mathrm{d}} 1130 \\
{ }^{\mathrm{d}} 1135 \\
{ }^{\mathrm{d}} 1140 \\
780 \\
{ }^{\mathrm{c}} 1000 \\
780 \\
790 \\
800 \\
900 \\
{ }^{\mathrm{c}} 1000 \\
{ }^{\mathrm{c}} 1050 \\
{ }^{\mathrm{c}} 1070\end{array}$ & $\begin{array}{c}h r \\
18 \\
18 \\
3 \\
2 \\
2 \\
62 \\
1.5 \\
1.5 \\
2 \\
22 \\
78 \\
18 \\
18 \\
20 \\
71 \\
18 \\
504 \\
2\end{array}$ & $\begin{array}{l}2: 1+\mathrm{Nd}_{2} \mathrm{O}_{3}+1: 1 \ldots \ldots \ldots \ldots \ldots \\
2: 1+\mathrm{Nd}_{2} \mathrm{O}_{3} \\
2: 1+\mathrm{Nd}_{2} \mathrm{O}_{3} \\
2: 1+\mathrm{Nd}_{2} \mathrm{O}_{3} \ldots \ldots \ldots \ldots \ldots \ldots \ldots \ldots \\
2: 1+\mathrm{Nd}_{2} \mathrm{O}_{3} \\
2: 1+\mathrm{Nd}_{2} \mathrm{O}_{3} \ldots \ldots \ldots \ldots \ldots \ldots \ldots \ldots \\
2: 1+\mathrm{Nd}_{2} \mathrm{O}_{3} \\
2: 1+\mathrm{Nd}_{2} \mathrm{O}_{3}+\mathrm{Pd} \ldots \ldots \ldots \ldots \ldots \ldots \\
2: 1+\mathrm{Nd}_{2} \mathrm{O}_{3}+\mathrm{Pd} \ldots \ldots \ldots \ldots \ldots \ldots \\
2: 1+\mathrm{Nd}_{2} \mathrm{O}_{3}+1: 1 \ldots \ldots \ldots \ldots \ldots \ldots \\
2: 1+\mathrm{Nd}_{2} \mathrm{O}_{3} \\
2: 1+\mathrm{Nd}_{2} \mathrm{O}_{3}+1: 1 \ldots \ldots \ldots \ldots \ldots \ldots \\
2: 1+\mathrm{Nd}_{2} \mathrm{O}_{3}+1: 1 \ldots \ldots \ldots \ldots \ldots \ldots \\
2: 1+\mathrm{Nd}_{2} \mathrm{O}_{3}+1: 1 \ldots \ldots \ldots \ldots \ldots \ldots \\
2: 1+\mathrm{Nd}_{2} \mathrm{O}_{3} \ldots \ldots \ldots \ldots \ldots \ldots \ldots \ldots \\
2: 1 \\
2: 1\end{array}$ & $\begin{array}{l}\text { Nonequilibrium. } \\
\text { Quenched in ice water. } \\
\text { Quenched in ice water. } \\
\text { Nonequilibrium. } \\
\text { Nonequilibrium. } \\
\text { Nonequilibrium. } \\
\text { Nonequilibrium. } \\
\text { Nonequilibrium. } \\
\text { Nonequilibrium. } \\
\text { Nonequilibrium. } \\
\end{array}$ \\
\hline
\end{tabular}


TABLE 1. Experimental data for compositions in the $\mathrm{Ln}_{2} \mathrm{O}_{3}-\mathrm{PdO}$ systems-Continued

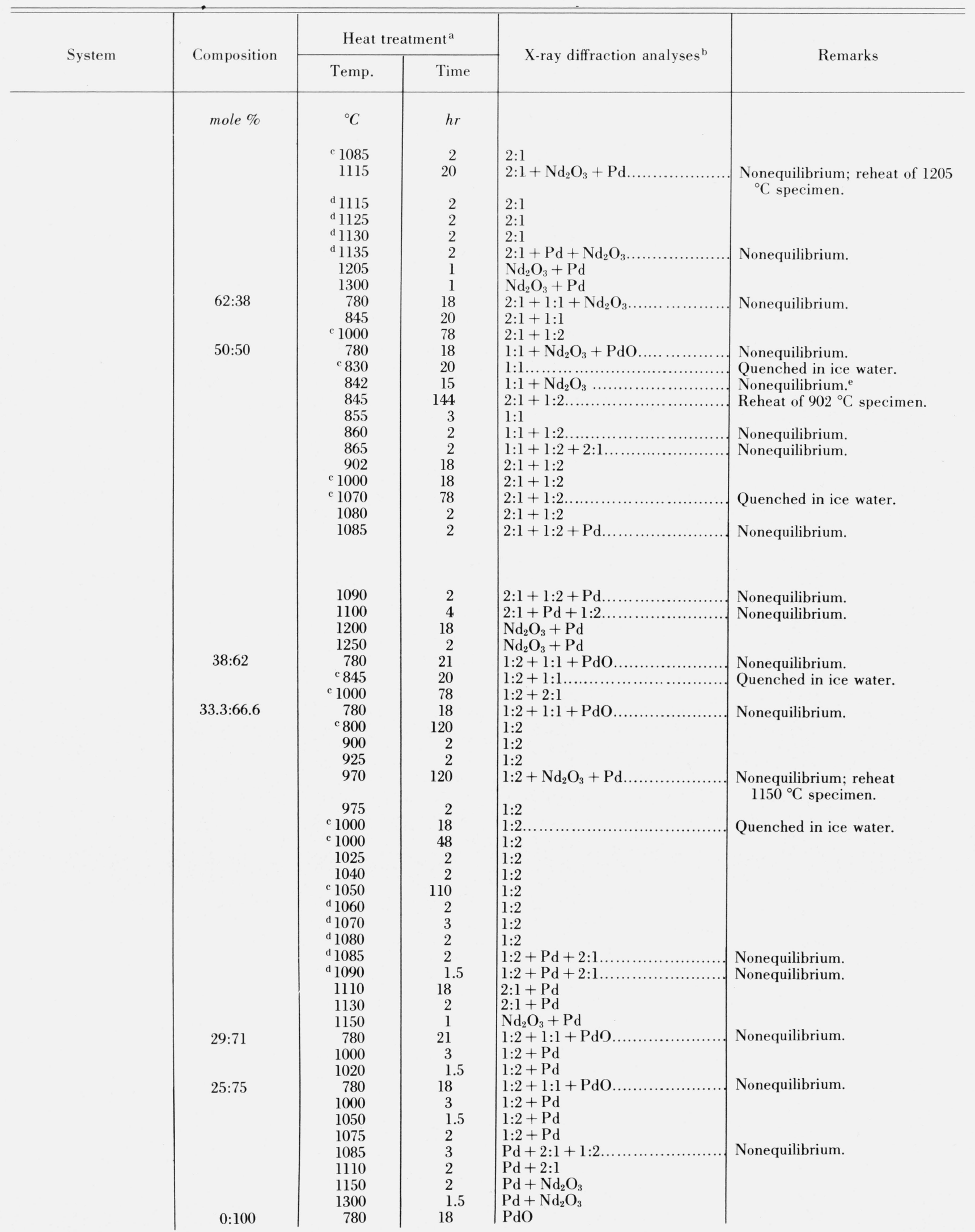


TABLE 1. Experimental data for compositions in the $\mathrm{Ln}_{2} \mathrm{O}_{3}-\mathrm{PdO}$ systems-Continued

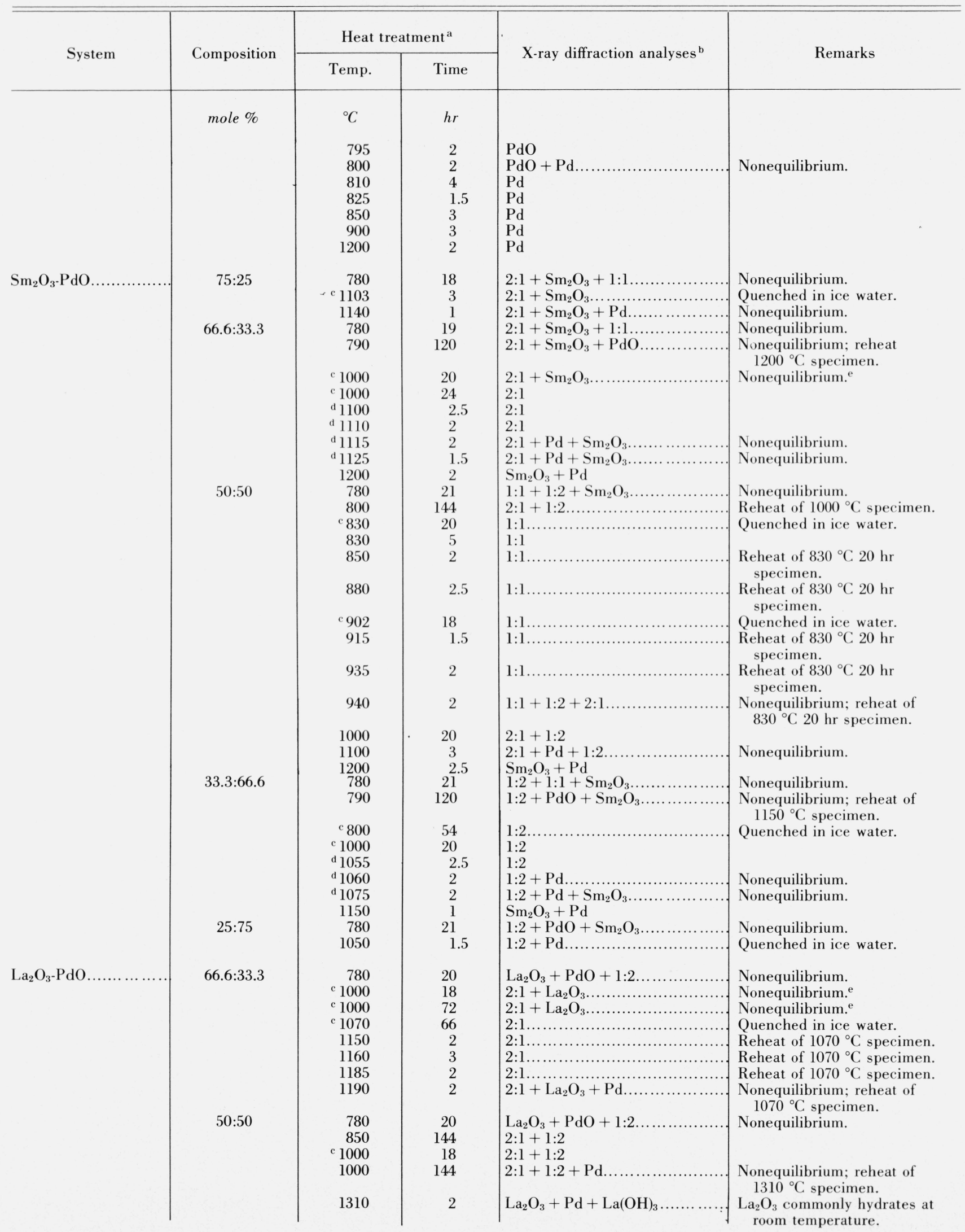


TABLE 1. Experimental data for compositions in the $\mathrm{Ln}_{2} \mathrm{O}_{3}-\mathrm{PdO}$ systems-Continued

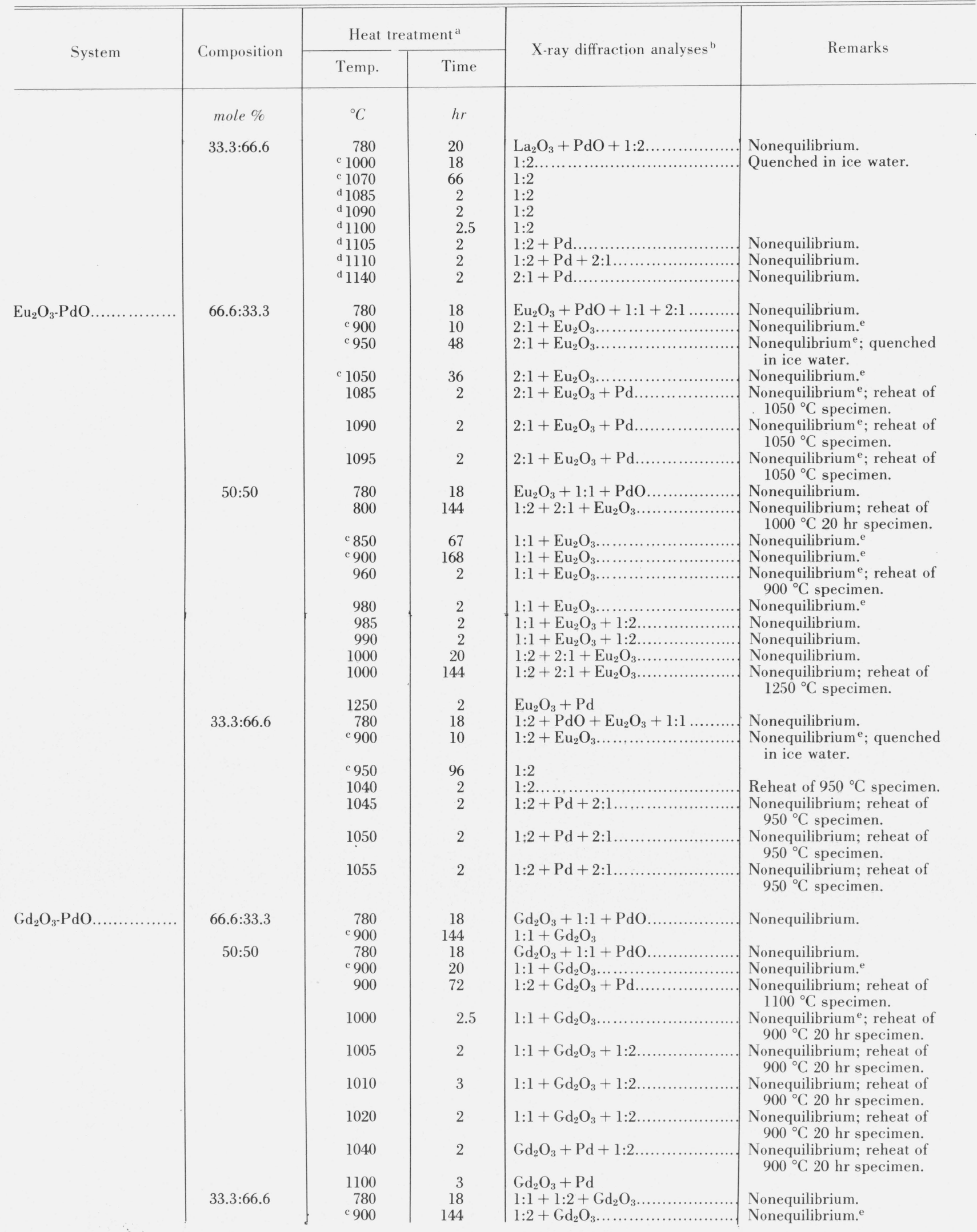


TABLE 1. Experimental data for compositions in the $\mathrm{Ln}_{2} \mathrm{O}_{3}-\mathrm{PdO}$ systems - Continued

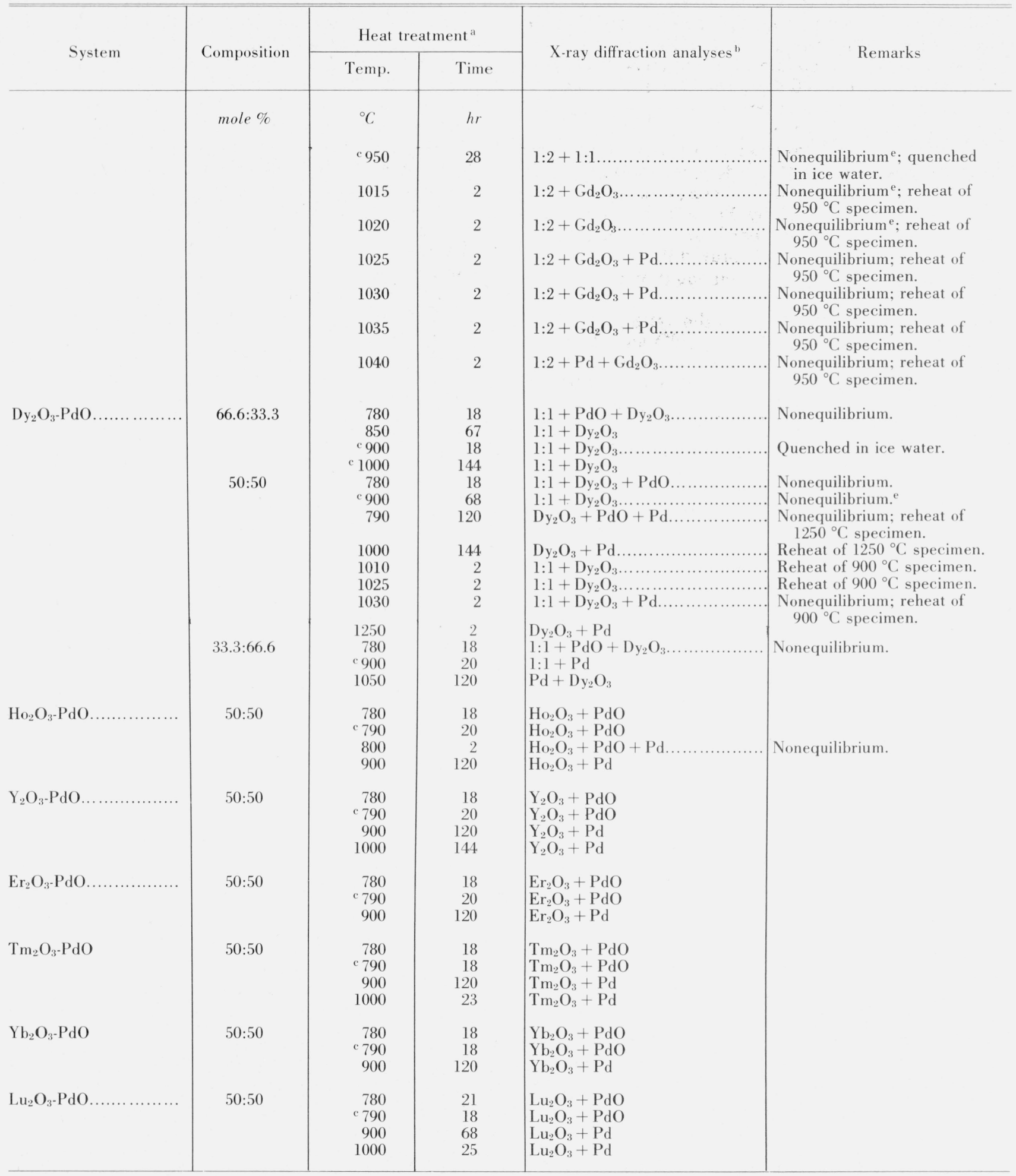

a All specimens were heat treated at $770{ }^{\circ} \mathrm{C}$, a minimum of $18 \mathrm{hr}$. Unless otherwise indicated, fused silica tubes (sealed at one end) were used for specimen containers and were air quenched.

${ }^{b}$ The phases identified are given in order of the relative amount present at room temperature.

c Sealed platinum tubes were used for specimen containers.

${ }^{\mathrm{d}}$ Reheat of $1000{ }^{\circ} \mathrm{C}$ specimen.

e $\mathrm{PdO}$ probably lost by volatilization. 
to establish the stability of the three compounds, appropriate mixtures were heated first above and then below their respective decomposition or dissociation temperatures. Only the $2: 1$ and $1: 2$ compounds reformed from their decomposition products. Prolonged heat treatments (up to 6 days) failed to reform the 1:1 compound, indicating perhaps it is metastable phase that forms only on heating.

A literature search did not reveal any compounds structurally similar to the $\mathrm{Nd}_{2} \mathrm{O}_{3} \cdot \mathrm{PdO}$ phases. The $x$-ray powder patterns of the compounds were not similar to those reported by Barry and Roy [15] for the $2: 1,1: 1$, and $1: 2$ rare earth oxide-calcium oxide compounds. The unindexed x-ray diffraction powder patterns for the three compounds found in the present study are given in table 2 .

At temperatures above $800{ }^{\circ} \mathrm{C}$ the system no longer can be represented by the $\mathrm{Nd}_{2} \mathrm{O}_{3}-\mathrm{PdO}$ join. The system changes through dissociation and at $1135{ }^{\circ} \mathrm{C}$ becomes the true binary $\mathrm{Nd}_{2} \Theta_{3}-\mathrm{Pd}$. $\mathrm{Up}$ to $1300{ }^{\circ} \mathrm{C}$, $\mathrm{Nd}_{2} \mathrm{O}_{3}$ and $\mathrm{Pd}$ do not react in the solid state.

TABLE 2. X-ray diffraction powder data for $\mathrm{Nd}_{2} \mathrm{O}_{3}-\mathrm{PdO}$ compounds

$\left(\mathrm{CuK}_{\alpha} \text { radiation }\right)^{\mathrm{a}}$

\begin{tabular}{|c|c|c|c|c|c|}
\hline \multicolumn{2}{|c|}{$2 \mathrm{Nd}_{2} \mathrm{O}_{3} \cdot \mathrm{PdO}^{\mathrm{b}}$} & \multicolumn{2}{|c|}{$\mathrm{Nd}_{2} \mathrm{O}_{3} \cdot \mathrm{Pd}^{\mathrm{c}}$} & \multicolumn{2}{|c|}{$\mathrm{Nd}_{2} \mathrm{O}_{3} \cdot 2 \mathrm{PdO}^{\mathrm{b}}$} \\
\hline$d$ & $I / I_{0}$ & $d$ & $I / I_{0}$ & $d$ & $I / I_{0}$ \\
\hline $\begin{array}{l}3.2840 \\
3.0064 \\
2.8723 \\
2.8643 \\
2.8038\end{array}$ & $\begin{array}{r}15 \\
100 \\
45 \\
81 \\
45\end{array}$ & $\begin{array}{l}3.1895 \\
2.8768 \\
2.8280 \\
2.0732 \\
1.9980\end{array}$ & $\begin{array}{r}17 \\
100 \\
60 \\
12 \\
33\end{array}$ & $\begin{array}{l}4.2387 \\
3.4568 \\
3.2733 \\
2.9303 \\
2.8228\end{array}$ & $\begin{array}{l}13 \\
12 \\
20 \\
28 \\
76\end{array}$ \\
\hline $\begin{array}{l}2.1401 \\
2.0827 \\
2.0170 \\
1.9746 \\
1.9313\end{array}$ & $\begin{array}{r}21 \\
20 \\
8 \\
19 \\
12\end{array}$ & $\begin{array}{l}1.9556 \\
1.6715 \\
1.6423 \\
1.4393 \\
1.4120\end{array}$ & $\begin{array}{r}8 \\
18 \\
27 \\
7 \\
9\end{array}$ & $\begin{array}{l}2.7792 \\
2.5924 \\
2.3178 \\
2.1372 \\
2.1185\end{array}$ & $\begin{array}{r}41 \\
100 \\
71 \\
12 \\
10\end{array}$ \\
\hline $\begin{array}{l}1.7640 \\
1.7199 \\
1.6888 \\
1.6800 \\
1.6628\end{array}$ & $\begin{array}{r}8 \\
9 \\
12 \\
22 \\
4\end{array}$ & 1.2641 & 5 & $\begin{array}{l}2.0732 \\
2.0347 \\
2.0179 \\
1.8192 \\
1.7804\end{array}$ & $\begin{array}{r}6 \\
9 \\
54 \\
20 \\
8\end{array}$ \\
\hline $\begin{array}{l}1.6137 \\
1.6019 \\
1.5784 \\
1.4342\end{array}$ & $\begin{array}{r}11 \\
11 \\
10 \\
6\end{array}$ & & & $\begin{array}{l}1.7287 \\
1.6634 \\
1.6148 \\
1.5898 \\
1.5732 \\
\\
1.5674 \\
1.5230 \\
1.4669 \\
1.4181 \\
1.3913 \\
\\
1.3807 \\
1.2971 \\
1.2753 \\
1.2281 \\
1.1870\end{array}$ & $\begin{array}{r}11 \\
7 \\
18 \\
11 \\
25 \\
\\
33 \\
31 \\
21 \\
15 \\
7 \\
11 \\
\\
\\
3 \\
11 \\
8 \\
4 \\
7\end{array}$ \\
\hline
\end{tabular}

a $d$-interplanar spacing, $I / I_{0}-$ relative intensity.

${ }^{b} \mathrm{X}$-ray pattern obtained from specimen heat treated at $1000{ }^{\circ} \mathrm{C}$ for $18 \mathrm{hr}$.

X-ray pattern obtained from specimen heat treated at $830{ }^{\circ} \mathrm{C}$ for $20 \mathrm{hr}$.

The equilibrium phase diagram for the $\mathrm{Sm}_{2} \mathrm{O}_{3}-\mathrm{PdO}$ system in air is given in figure 2 . The pertinent data are listed in table 1. The diagram is similar to the $\mathrm{Nd}_{2} \mathrm{O}_{3}-\mathrm{PdO}$ system in many respects in that three intermediate compounds $2: 1$, metastable $1: 1$, and $1: 2$ also occur. These phases dissociate or decompose at 1115,940 , and $1060^{\circ} \mathrm{C}$, respectively.

\subsection{Other $\operatorname{Ln}_{2} \mathrm{O}_{3}-\mathrm{PdO}$ Systems in Air}

Mixtures were prepared from $\mathrm{PdO}$ and each of the following sesquioxides: $\mathrm{La}_{2} \mathrm{O}_{3}, \mathrm{Eu}_{2} \mathrm{O}_{3}, \mathrm{Gd}_{2} \mathrm{O}_{3}, \mathrm{Dy}_{2} \mathrm{O}_{3}$, $\mathrm{Ho}_{2} \mathrm{O}_{3}, \mathrm{Y}_{2} \mathrm{O}_{3}, \mathrm{Er}_{2} \mathrm{O}_{3}, \mathrm{Tm}_{2} \mathrm{O}_{3}, \mathrm{Yb}_{2} \mathrm{O}_{3}$, and $\mathrm{Lu}_{2} \mathrm{O}_{3}$. The phase equilibrium diagrams for the various $\mathrm{Ln}_{2} \mathrm{O}_{3}$ $\mathrm{PdO}$ systems in air are given in figure 3. The experimental data are tabulated in table 1 . It is evident that the $\mathrm{Nd}_{2} \mathrm{O}_{3}-\mathrm{PdO}$ system is representative in a general way of the other $\mathrm{Ln}_{2} \mathrm{O}_{3}-\mathrm{PdO}$ systems. The $\mathrm{La}_{2} \mathrm{O}_{3}-\mathrm{PdO}$ diagram indicates the occurrence of the 2:1 and the $1: 2$ compounds. The 1:1 compound was not detected. Three compounds, $2: 1$, metastable $1: 1$, and $1: 2$ occur in the $\mathrm{Eu}_{2} \mathrm{O}_{3}-\mathrm{PdO}$ system. The $1: 2$ and metastable 1:1 compounds occur in the $\mathrm{Gd}_{2} \mathrm{O}_{3}-\mathrm{PdO}$ system. The $2 \mathrm{Gd}_{2} \mathrm{O}_{3} \cdot \mathrm{PdO}$ compound was not detected. In the $\mathrm{Dy}_{2} \mathrm{O}_{3}-\mathrm{PdO}$ system, only the metastable $1: 1$ compound was detected.

The remaining systems of either $\mathrm{Ho}_{2} \mathrm{O}_{3}, \mathrm{Y}_{2} \mathrm{O}_{3}, \mathrm{Er}_{2} \mathrm{O}_{3}$, $\mathrm{Tm}_{2} \mathrm{O}_{3}, \mathrm{Yb}_{2} \mathrm{O}_{3}$, or $\mathrm{Lu}_{2} \mathrm{O}_{3}$ with $\mathrm{PdO}$ are rather simple and straightforward inasmuch as there was no detectable reaction between end members in the solid state. The diagrams indicate only the dissociation of $\mathrm{PdO}$, the point at which the system reverts to the true $\mathrm{Ln}_{2} \mathrm{O}_{3}$ $\mathrm{Pd}$ system.

Table 3 summarizes the results obtained in this study. Listed are the systems investigated, size of the rare earth cation, and the dissociation temperatures of the $\mathrm{Ln}_{2} \mathrm{O}_{3}-\mathrm{PdO}$ compounds. The dissociation temperatures of the 2:1 compounds decrease as the size of the rare earth cation decreases. The $1: 2$ compounds were found to dissociate in a similar manner. However, the decomposition temperatures of the metastable 1:1 compounds increase as the size of the rare earth cation decreases. As expected, the $\mathrm{Ln}_{2} \mathrm{O}_{3}-\mathrm{PdO}$ compounds with the same molecular ratio appear to have similar x-ray patterns. The patterns indicate appropriate shift in $d$-spacings to account for difference in ionic size of the rare earth cations.

It should be noted that the proposed diagrams pertain only to the phase relations of the systems in an air environment at atmospheric pressure. Any change in oxygen pressure would change the equilibrium diagram. In an air environment, precaution should be taken when utilizing $\mathrm{Pd}$ metal in combination with some of the rare earth oxides, since the data indicate the tendency to form new phases.

\subsection{Summary}

Equilibrium phase diagrams for systems involving $\mathrm{PdO}$ and various rare earth oxides were determined in air. Selected mixtures in the systems were studied by x-ray diffraction techniques after various heat treatments. Palladium, in air, oxidizes to $\mathrm{PdO}$ at moderate temperatures. The dissociation temperature of $\mathrm{PdO}$ in air at atmospheric pressure was established at $800 \pm 5{ }^{\circ} \mathrm{C}$. This dissociation was found to be a reversible process. Palladium oxide reacts with a number of oxides to form binary compounds. The pseudobinary system $\mathrm{Nd}_{2} \mathrm{O}_{3}-\mathrm{PdO}$ exemplified the typical type of reaction and was studied in detail. Three compounds, $2 \mathrm{Nd}_{2} \mathrm{O}_{3} \cdot \mathrm{PdO}, \mathrm{Nd}_{2} \mathrm{O}_{3} \cdot \mathrm{PdO}$ (meta- 


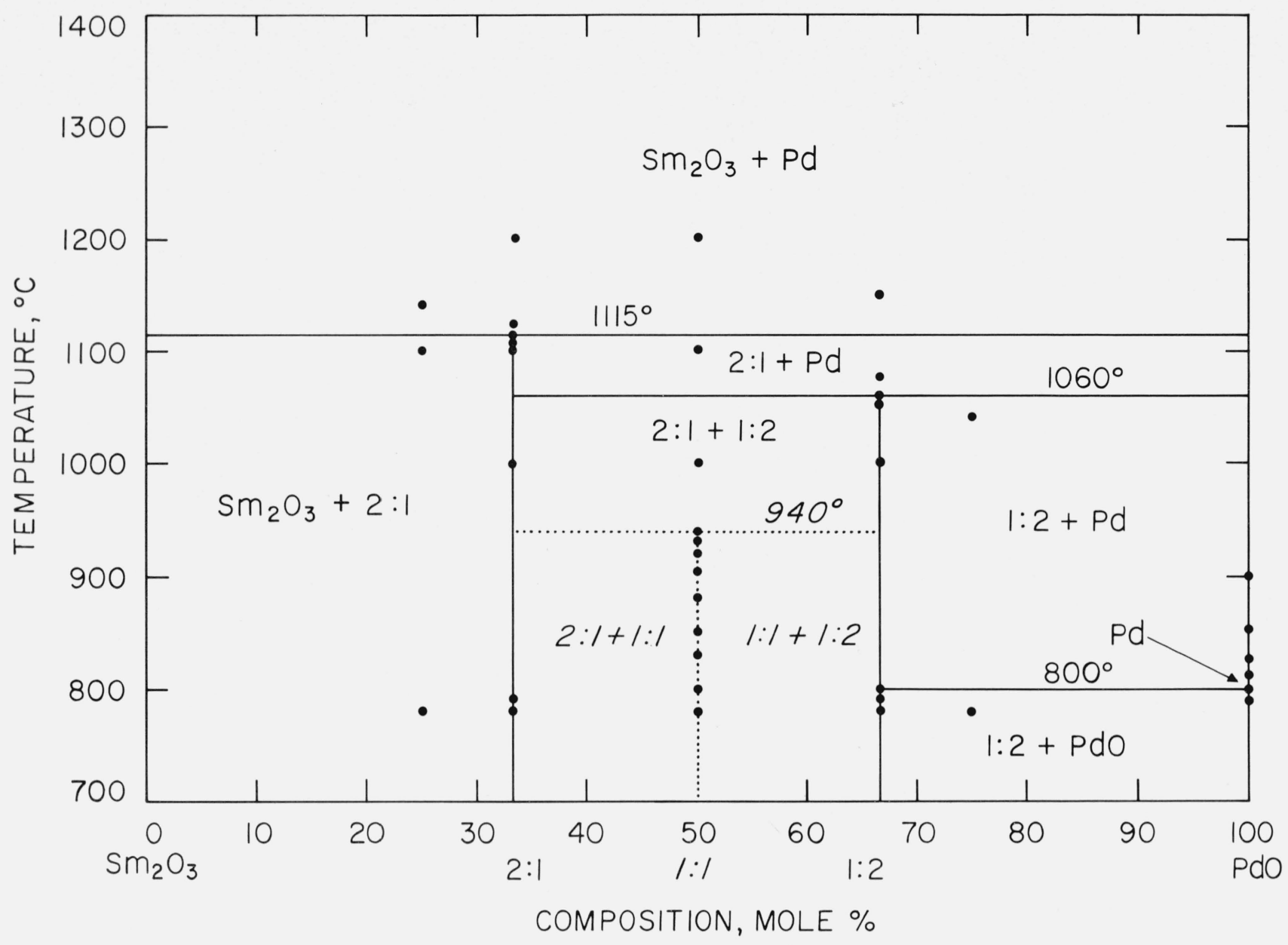

Figure 2. Phase equilibrium diagram for the $\mathrm{Sm}_{2} \mathrm{O}_{3}-\mathrm{PdO}$ system in air.

Dotted lines indicate metastable 1:1 compound and decomposition temperature. Italic lettering indicates metastable phase assemblages.

- compositions and temperatures of experiments conducted.

stable), and $\mathrm{Nd}_{2} \mathrm{O}_{3} \cdot 2 \mathrm{PdO}$ occur in the system. The $2: 1,1: 1$, and $1: 2$ compounds, of unknown symmetry dissociate or decompose at 1135,860 , and $1085{ }^{\circ} \mathrm{C}$, respectively. Above $1135{ }^{\circ} \mathrm{C}$ the system corresponds to the $\mathrm{Nd}_{2} \mathrm{O}_{3}-\mathrm{Pd}$ binary system. No further reaction appears to take place between $\mathrm{Nd}_{2} \mathrm{O}_{3}$ and $\mathrm{Pd}$ up to $1300{ }^{\circ} \mathrm{C}$. Similar type compounds were found to exist in other $\mathrm{Ln}_{2} \mathrm{O}_{3}-\mathrm{PdO}$ systems.

Three compounds, 2:1, $1: 1$, and $1: 2$, occur in the $\mathrm{Sm}_{2} \mathrm{O}_{3}-\mathrm{PdO}$ and $\mathrm{Eu}_{2} \mathrm{O}_{3}-\mathrm{PdO}$ systems. Two compounds,
$2: 1$ and $1: 2$, occur in the $\mathrm{La}_{2} \mathrm{O}_{3}-\mathrm{PdO}$ system. Other compounds detected were the $1: 1$ and $1: 2$ in the $\mathrm{Gd}_{2} \mathrm{O}_{3}-\mathrm{PdO}$ system and the $1: 1$ in the $\mathrm{Dy}_{2} \mathrm{O}_{3}-\mathrm{PdO}$ system. Each of these compounds also dissociated upon heating at temperatures above the dissociation temperature of $\mathrm{PdO}$. Mixtures of either $\mathrm{Ho}_{2} \mathrm{O}_{3}, \mathrm{Y}_{2} \mathrm{O}_{3}$, $\mathrm{Er}_{2} \mathrm{O}_{3}, \mathrm{Tm}_{2} \mathrm{O}_{3}, \mathrm{Yb}_{2} \mathrm{O}_{3}$, or $\mathrm{Lu}_{2} \mathrm{O}_{3}$ with $\mathrm{PdO}$ did not react in the solid state. 

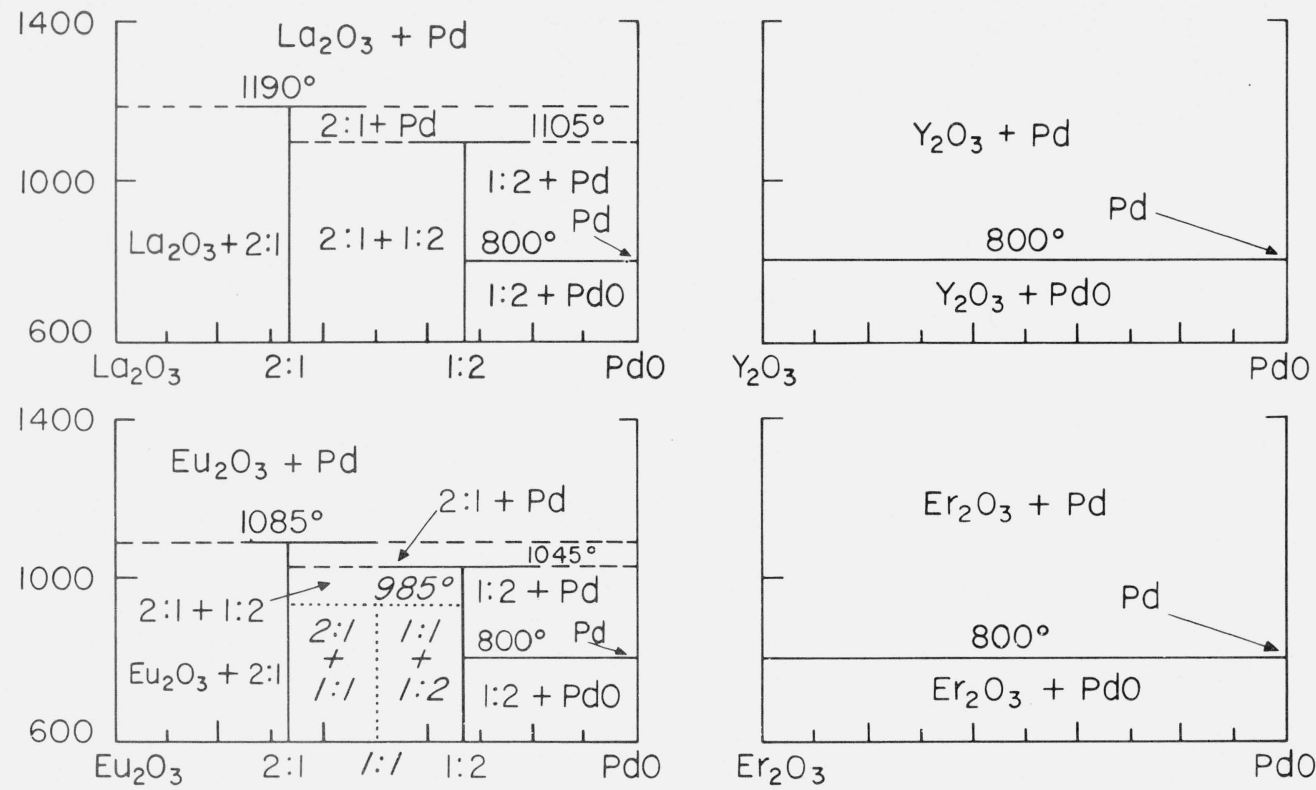

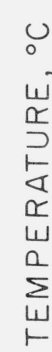
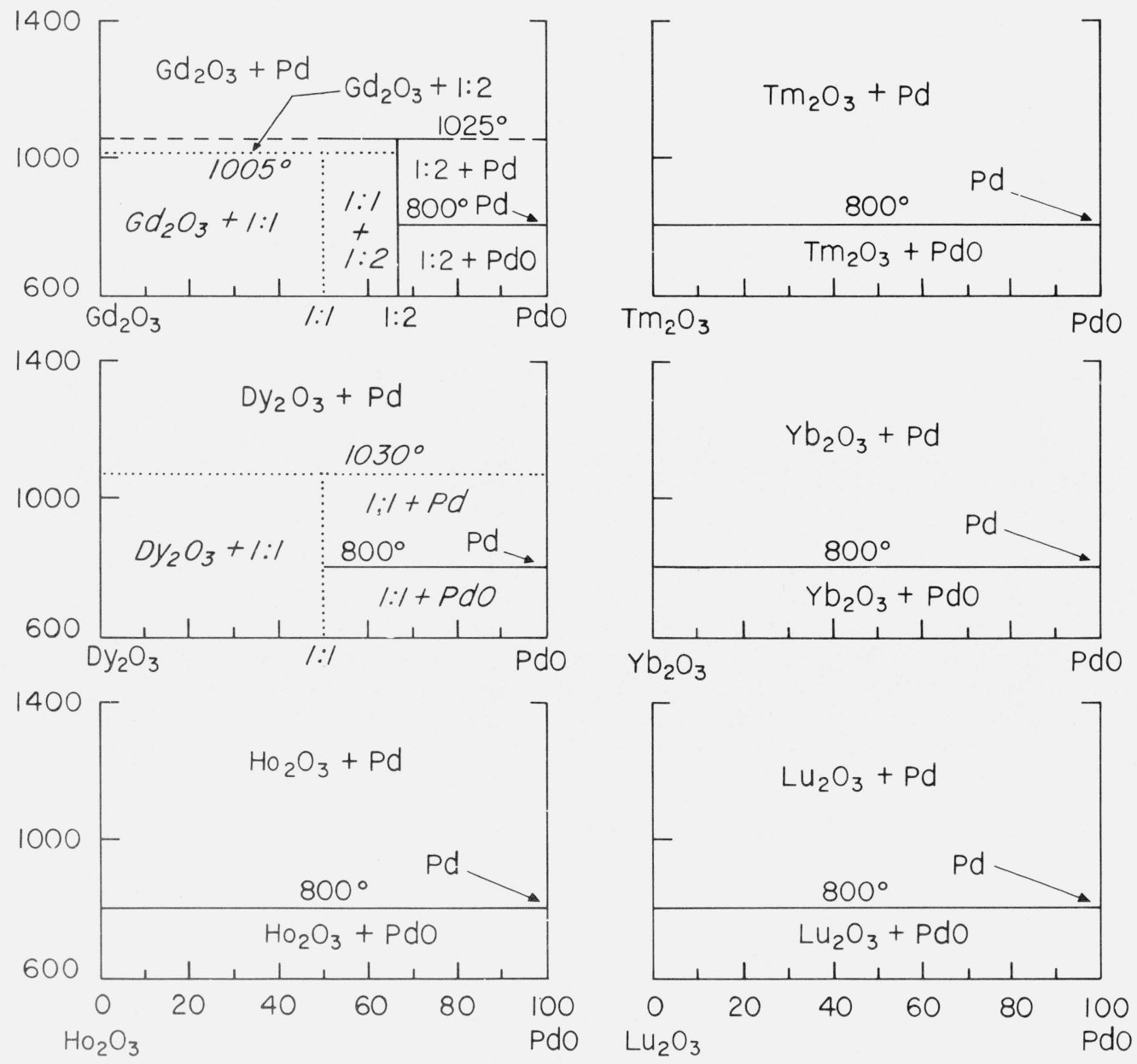

COMPOSITION, MOLE \%

Figure 3. Proposed phase equilibrium diagrams for various $\mathrm{Ln}_{2} \mathrm{O}_{3}-\mathrm{PdO}$ systems in air.

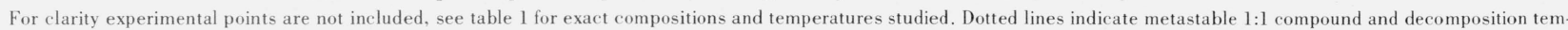
perature. Italic lettering indicates metastable phase assemblages. 


\begin{tabular}{|c|c|c|c|c|}
\hline \multirow[b]{2}{*}{ SYSTEM } & \multirow{2}{*}{$\begin{array}{l}\text { RADIUS OF } \\
\operatorname{Ln}^{+3} \AA\end{array}$} & \multicolumn{3}{|c|}{ DISSOCIATION TEMP. ${ }^{\circ} \mathrm{C}$} \\
\hline & & $2 \operatorname{Ln}_{2} O_{3} \cdot P d 0$ & $\operatorname{Ln}_{2} O_{3} \cdot P d O$ & $\operatorname{Ln}_{2} O_{3} \cdot 2 P d O$ \\
\hline $\mathrm{La}_{2} \mathrm{O}_{3}-\mathrm{PdO}$ & 1.14 & 1190 & - & 1105 \\
\hline $\mathrm{Nd}_{2} \mathrm{O}_{3}-\mathrm{PdO}$ & 1.04 & 1135 & $(860)$ & 1085 \\
\hline $\mathrm{Sm}_{2} \mathrm{O}_{3}-\mathrm{PdO}$ & 1.00 & 1115 & $(940)$ & 1060 \\
\hline $\mathrm{Eu}_{2} \mathrm{O}_{3}-\mathrm{PdO}$ & 0.98 & 1085 & (985) & 1045 \\
\hline $\mathrm{Gd}_{2} \mathrm{O}_{3}-\mathrm{PdO}$ & 0.97 & - & $(1005)$ & 1025 \\
\hline $\mathrm{Dy}_{2} \mathrm{O}_{3}-\mathrm{PdO}$ & 0.92 & & $(1030)$ & 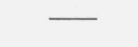 \\
\hline $\mathrm{H}_{2} \mathrm{O}_{3}-\mathrm{PdO}$ & 0.91 & & & \\
\hline $\mathrm{Y}_{2} \mathrm{O}_{3}-\mathrm{PdO}$ & 0.91 & - & - & - \\
\hline $\mathrm{Er}_{2} \mathrm{O}_{3}-\mathrm{PdO}$ & 0.89 & - & . & - \\
\hline $\mathrm{Tm}_{2} \mathrm{O}_{3}-\mathrm{PdO}$ & 0.87 & - & $\longrightarrow$ & - \\
\hline $\mathrm{Yb}_{2} \mathrm{O}_{3}-\mathrm{PdO}$ & 0.86 & 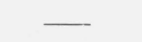 & - & - \\
\hline $\mathrm{Lu}_{2} \mathrm{O}_{3}-\mathrm{Pd} 0$ & 0.85 & - & 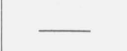 & - \\
\hline
\end{tabular}

TABLE 3. Dissociation temperatures of $\mathrm{Ln}_{2} \mathrm{O}_{3} \cdot \mathrm{PdO}$ compounds. All radii of the rare earth cations taken from Arhens [16] with the exception of $\mathrm{Y}+3$ which was taken from Roth and Schneider [8]. Parenthesis indicate decomposition temperatures of metastable $1: 1$ compounds.

\section{References}

[1] S. J. Schneider, J. L. Waring, and R. E. Tressler, J. Res. NBS 69A (Phys. and Chem.), No. 3, 245-54 (1965).

[2] C. L. McDaniel and S. J. Schneider, J. Res. NBS 71 A (Phys. and Chem.), No. 2, 119-23 (1967).

[3] H. F. Stimson, J. Res. NBS 65A (Phys, and Chem.), No. 3, 139-45 (1960).

[4] H. E. Swanson and E. Tatge, NBS Circ. 539, I, 21 (1953).

[5] H. E. Swanson, R. K. Fuyat, and G. M. Ugrinic, NBS Circ. $539,4,27$ (1963).

[6] W. E. Bell, R. E. Inyard, and M. Tagami, J. Phys. Chem. 70 [11], 3735-36 (1966)

[7] H. E. Swanson, R. K. Fuyat, and G. M. Ugrinic, NBS Circ $539,4,26(1963)$

[8] R. S. Roth and S. J. Schneider, J. Res. NBS 64A (Phys. and Chem.) No. 4, 309-16 (1960).

[9] S. J. Schneider, NBS Monograph 68, 31 p. (1963).

[10] S. J. Schneider and R. S. Roth, J. Res. NBS 64A (Phys. and Chem.) No. 4, 317-32 (1960)

[11] S. J. Schneider, J. Res. NBS 65A (Phys. and Chem.), No. 5, 429-34 (1961).

[12] A. Muan, Am. J. Sci. 256, 171-207 (1958).

[13] E. Raub, J. Less Common Metals 1, 3-18 (1959).

[14] J. C. Chaston, Platinum Metals Rev. 9 [4], 126-9 (1965).

[15] T. L. Barry, V. S. Stubican, and R. Roy, J. Am. Ceram. Soc. 49 [12], 667-70 (1966).

[16] L. H. Ahrens, Geochim. et Cosmochim. Acta 2, 155-69 (1952).

(Paper 72Al-479) 